\title{
Pengaruh Entepreneurial Leadership dan Budaya Kerja terhadap Employee Engagement Dengan Budaya Kerja dan Organizational Trust sebagai Variabel Mediator Pada Pegawai di Kementerian Agama RI
}

\author{
Ivan Yulivan \\ Program Studi Ekonomi Pertahanan, Universitas Pertahanan, Indonesia \\ Email korepondensi: ivanyulivan42@gmail.com
}

\begin{abstract}
ABSTRAK
Penelitian ini bertujuan untuk menguji secara empiris pengaruh entepreneurial leadership terhadap employee engagement dengan budaya kerja sebagai mediator, pengaruh entepreneurial leadership terhadap employee engagement dengan organizational trust sebagai mediator dan pengaruh budaya kerja berpengaruh terhadap employee engagement dengan organizational trust sebagai mediator yang diambil oleh pegawai. Analisis ini menggunakan variabel independen yaitu entepreneurial leadership dan budaya kerja. Variabel dependentnya adalah employee engagement dan variabel moderasi adalah budaya kerja dan organizational trust. Sampel penelitian ini adalah pegawai di kementerian agama RI. Sampel dilakukan dengan metode survei dengan teknik proportional random sampling. Pengumpulan data dilakukan dengan dengan kuesioner disebarkan langsung oleh pegawai sebanyak 325 kuesioner. Metode statistik menggunakan analisis jalur (path analysis), dengan pengujian hipotesis uji statistik t. Hasil penelitian ini menunjukan bahwa entepreneurial leadership dan budaya kerja berpengaruh langsung positif terhadap employee engagement dengan budaya kerja dan organizational trust sebagai mediator.
\end{abstract}

Keywords: entepreneurial leadership, employee engagement, budaya kerja, organizational trust

\section{ABSTRACT}

This research aims to empirically test the influence of entepreneurial leadership on employee engagement with work culture as a mediator, the influence of entepreneurial leadership on employee engagement with organizational trust as a mediator and the influence of work culture affects employee engagement with organizational trust as a mediator taken by the officer. This analysis uses independent variables, namely entepreneurial leadership and work culture. The dependent variable is employee engagement and the moderation variable is work culture and organizational trust. This research sample is an employee in the Ministry of Religious Affairs. The sample is conducted by survey method with proportional random samplingtechnique. Data collection is done with questionnaires distributed directly by employees as many as 325 questionnaires. Statistical methods use path analysis, by testing the statistical test hypothesis $t$. This research shows that entepreneurial leadership and work culture have a direct positive effect on employee engagement with work culture and organizational trust as mediators.

Keywords: entepreneurial leadership, employee engagement, work culture, organizational trust

\section{PENDAHULUAN}


Menurut Renko et al. (2013) entepreneurial leadership merupakan kepemimpinan yang meletakkan fokus gaya kepemimpinannya pada peningkatan kreativitas, inovasi, serta keberanian mengambil resiko sebagai gaya kepemimpinan untuk menghadapi dinamika lingkungan strategis. Disisi lain Dabic et al. (2020) menjelaskan bahwa entepreneurial leadership diasumsikan dapat mempengaruhi employee engagement karena entepreneurial leadership akan mampu memperlakukan pegawainya secara kreatif, sehingga pegawai bersedia memberikan kemampuan optimalnya terhadap organisasi. Dengan demikian, entepreneurial leadership merupakan variable antecedent dari employee engagement (Christian, 2011). Employee engagement merujuk pada kondisi keterikatan seseorang dalam bekerja. Keterikatan diantara pegawai menunjukkan adanya keterlibatan secara emosional, kognitif dan fisik yang kemudian memotivasi mereka dalam menyelesaikan tugas dengan perasaan puas dan antusias Invalid source specified. Penelitian mengamati terdapat kompleksitas permasalahan yang saling berhubungan terkait dengan employee engagement di Kementerian Agama. Berdasarkan hasil analisa, dapat diidentifikasi permasalahan relevan, yakni: tingkat disiplin dan inovasi kerja yang rendah, motivasi kerja yang rendah, suka menunda-nunda tugas, kurangnya kerja sama team, serta etos kerja yang rendah yang keseluruhannya menunjukkan indikasi rendahnya employee engagement.

Kerangka teori Integrative Model of Organizational Behavior (Colquitt, 2009) menjelaskan bahwa mekanisme organisasi, mekanisme group, dan karakteristik individu berkolaborasi dengan mekanisme individu akan menghasilkan yakni kinerja dan komitmen organisasi individu. Penelitian melihat bahwa kolaborasi antara mekanisme organisasi dengan mekanisme individu yang menghasilkan kinerja dan komitmen organisasi dari Colquitt pada akhirnya akan menghasilkan kesediaan pegawai untuk terikat kepada organisasi atau disebut sebagai employee engagement.

Budaya kerja merupakan kebiasaan yang secara berulang oleh para pegawai yang ditumbuhkan sehingga menjadi suatu sistem nilai, persepsi, perilaku, dan keyakinan yang dianut oleh setiap pegawai (Anitha, 2014). Budaya kerja diasumsikan mempengaruhi employee engagement karena budaya kerja yang memberikan kenyamanan kepada pegawai akan membuat pegawai merasa engaged (Bija, 2020). Sedangkan organizational trust diasumsikan mempengaruhi employee engagement karena pegawai yang percaya terhadap organisasi akan merasa engaged (Yildiz, 2017). Dalam penelitian ini budaya kerja dan organizational trust dijadikan variabel mediator dikarenakan peneliti menemukan addanya hubungan tidak langsung antara satu variabel dengan variabel lain. Terdapat satu variabel yang memperantai keduanya. Variabel perantara inilah yang disebut mediator atau intervening.

Kementerian Agama RI menghadapi tantangan besar pengelolaan organisasi dalam abad 21 ini, baik pada level organisasi maupun individu. Pada level organisasi, tantangan muncul dalam bentuk tuntutan pemenuhan berbagai standar pelayanan public yang harus dipenuhi organisasi untuk mewujudkan good governance. Sedangkan pada level individu, tantangan muncul dalam bentuk semakin kuatnya tuntutan kompetensi professional serta daya tarik organisasi private yang menawarkan salary lebih tinggi. Peneliti melihat bahwa tantangan organisasi yang dihadapi Kementerian Agama merupakan field study yang layak diamati lebih mendalam, untuk menemukan solusi yang dapat membantu Kementerian Agama meningkatkan kinerja organisasinya, sekaligus mampu mempertahankan Aparatur terbaiknya sebagai human capital organisasi. Dengan demikian, penelitian ini melihat bahwa mekanisme peningkatan kinerja organisasi Kementerian Agama merupakan satu kesatuan terintegrasi dengan mekanisme pengelolaan Aparatur SDM di Kementerian Agama seperti yang dijelaskan dalam teori (Colquitt, 2009) yang dikenal sebagai Integrative Model of Organizational Behavior. 


\section{METODE PENELITIAN}

Populasi dalam penelitian ini adalah seluruh pegawai (ASN) Kementerian Agama RI. Secara keseluruhan, jumlah populasi adalah sebanyak 2.731 orang, sedangkan yang menjadi unit analisisnya adalah pegawai dengan Golongan/Pangkat III sebanyak 2066 orang. Berdasarkan populasi penelitian tersebut, penelitian ini menentukan jumlah sampel dengan menggunakan rumus Slovin. Sehingga, sampel penelitian ini adalah sebanyak 335,1176 dan dibulatkan menjadi 325 orang yang akan diambil dengan menggunakan teknik proportional random sampling dari setiap satuan kerja Kementerian Agama Pusat. Untuk keperluan ujicoba, instrumen akan diberikan kepada 30 orang pegawai di luar sampel penelitian tersebut di atas. Alat pengumpul data utama adalah angket (kuesioner). Pengembangan instrument untuk setiap variabel diuraikan mulai dari definisi konseptual, definisi operasional, kisi-kisi instrument, jenis instrument serta pengujian validitas dan perhitungan reliabilitas instrument.

\section{HASIL DAN PEMBAHASAN}

\section{Uji Normalitas}

Uji normalitas dilakukan untuk mengetahui sejauh mana data dinyatakan berdistribusi normal. Dalam hal ini, penelitian menggunakan uji Lilliefors dengan menggunakan bantuan SPSS, yang hasilnya dituangkan dalam tabel 1 di bawah:

Tabel 1. Uji Normalitas Kolmogorov-Smirnov Variabel Penelitian

\begin{tabular}{|l|c|c|c|c|c|c|c|}
\hline & \multicolumn{2}{c}{ Kolmogorov-Smirnov } & \multicolumn{3}{c|}{ Shapiro-Wilk } \\
\hline Statistic & Df & Sig. & Statistic & Df & Sig. \\
\hline $\begin{array}{l}\text { Entepreneurial } \\
\text { Leadership }\end{array}$ & .042 & 335 & $.200^{*}$ & & .995 & 335 & .336 \\
\hline Budaya Kerja & & & & & & \\
\hline Organizational Trust & .048 & 335 & .063 & .995 & 335 & .349 \\
\hline Employee Engagement & .046 & 335 & .080 & .994 & 335 & .271 \\
\hline
\end{tabular}

Sumber: data diolah, 2021

Berdasarkan tabel 1 menunjukan bahwa Variabel Entepreneurial Leadership (X1) mendapatkan angka 0.200, signifikansi $>0.05$, sehingga data disimpulkan normal. Variabel Budaya Kerja (X2) dan (M) mendapatkan angka 0.063, signifikansi > 0.05, sehingga data disimpulkan normal. Variabel Organizational Trust (M) mendapatkan angka 0.080, signifikansi > 0.05, sehingga data disimpulkan normal, dan Variabel Employee Engagement (Y) mendapatkan angka 0.200, signifikansi > 0.05, sehingga data disimpulkan normal. Karena pengujian normalitas data menunjukkan hasil bahwa data penelitian berdistribusi normal, maka, pengujian hipotesis dengan menggunakan analisis jalur (Path Analysis) dapat dilakukan.

Entepreneurial Leadership Berpengaruh Secara Tidak Langsung terhadap Employee Engagement melalui Budaya Kerja

Untuk menguji seberapa besar peran variabel Budaya Kerja (M) memediasi pengaruh Entepreneurial Leadership $\left(\mathrm{X}_{1}\right)$ terhadap Employee Engagement $(\mathrm{Y})$ digunakan uji Sobel Test. Untuk dapat melihat signifikansi pengaruh tidak langsung, digunakan strategi Product of Coefficient dengan nilai $\mathrm{Z}>1.96$. 
Tabel 2. Koefisien Entepreneurial Leadership dan Budaya Kerja terhadap Employee Engagement

Coefficients $^{\mathrm{a}}$

Model Unstandardized Coefficients

1 (Constant)

ENTEPRENEURIAL

LEADERSHIP

BUDAYA KERJA

a. Dependent Variable: EMPLOYEE ENGAGEMENT

\section{B}

43.221

.520

Std. Error

5.969

.048

.046
Standardized

Coefficients

Beta

Dari table 2 hasil regresi di atas menunjukkan bahwa nilai koefisien regresi Entepreneurial Leadership terhadap Budaya Kerja sebesar 0.520 dengan standar error 0.048 dan nilai signifikansi 0.000, kemudian Budaya Kerja mendapatkan nilai koefisien 0.153 dengan standar error 0.046 dan nilai signifikansi 0.001. Dengan begitu, Entepreneurial Leadership secara signifikan berpengaruh langsung Budaya Kerja, dan demikian pula Budaya Kerja signifikan berpengaruh langsung terhadap Employee Engagement. Jika divisualisasikan, maka akan terbentuk model seperti gambar di bawah.

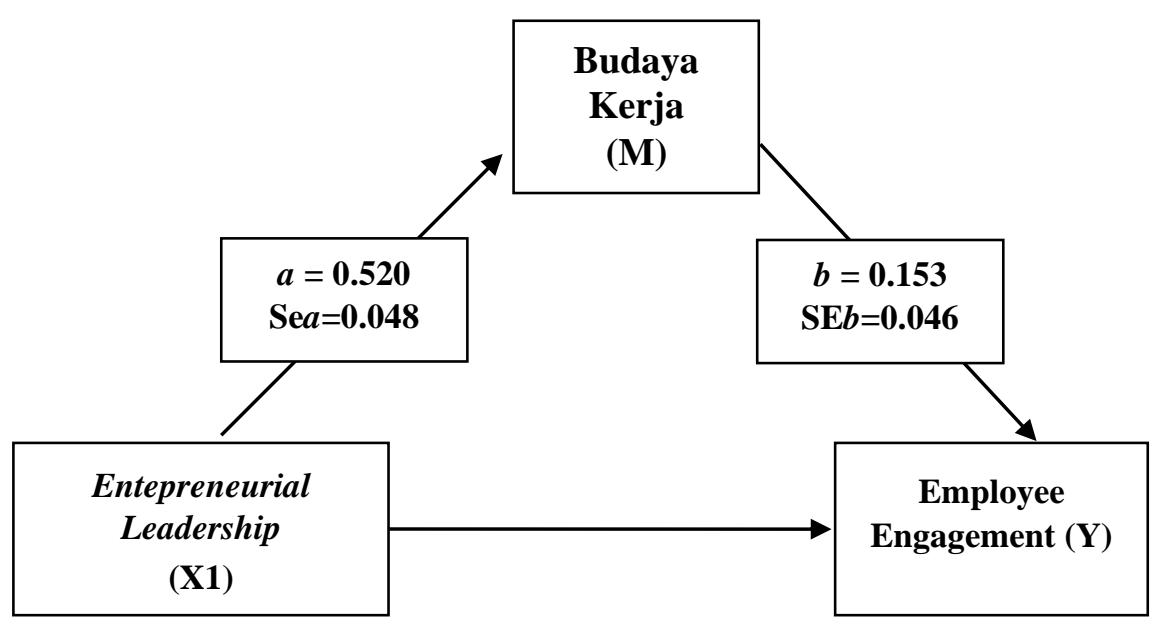

Gambar 1. Budaya Kerja sebagai Mediator Entepreneurial Leadership terhadap Employee Engagement

Model di atas merupakan model yang terbentuk dari hasil regresi pertama dan kedua, sehingga membentuk model analisis jalur (path analysis) dengan Budaya Kerja sebagai mediatornya. Nilai z dari Sobel Test tidak dapat dihasilkan langsung dari hasil regresi tetapi dengan perhitungan manual dengan rumus Sobel Test.

\section{Entepreneurial Leadership Berpengaruh Secara Tidak Langsung terhadap Employee Engagement melalui Organizational Trust}

Hasil uji model regresi dengan SPSS, menggunakan 3 variabel yaitu Entepreneurial Leadership sebagai variabel dependen, Organizational Trust sebagai Mediator dan Employee Engagement sebagai variabel dependennya. 
Tabel 3. Koefisien Entepreneurial Leadership dan Organizational Trust terhadap Employee Engagement

\begin{tabular}{|c|c|c|c|c|c|c|}
\hline \multicolumn{7}{|c|}{ Coefficients $^{\mathrm{a}}$} \\
\hline \multirow{2}{*}{\multicolumn{2}{|c|}{ Model }} & \multicolumn{2}{|c|}{$\begin{array}{l}\text { Unstandardized } \\
\text { Coefficients }\end{array}$} & \multirow{3}{*}{$\begin{array}{c}\text { Standardized } \\
\text { Coefficients } \\
\text { Beta }\end{array}$} & \multirow[t]{2}{*}{$\mathrm{t}$} & \multirow[t]{2}{*}{ Sig. } \\
\hline & & B & Std. Error & & & \\
\hline \multirow[t]{3}{*}{1} & (Constant) & $\begin{array}{r}10.71 \\
9\end{array}$ & 5.512 & & 1.945 & .053 \\
\hline & $\begin{array}{l}\text { ENTEPRENEURIAL } \\
\text { LEADERSHIP }\end{array}$ & .467 & .036 & .476 & $\begin{array}{r}12.81 \\
2\end{array}$ & .000 \\
\hline & $\begin{array}{l}\text { ORGANIZATIONAL } \\
\text { TRUST }\end{array}$ & .463 & .037 & .472 & $\begin{array}{r}12.68 \\
5\end{array}$ & .000 \\
\hline
\end{tabular}

a. Dependent Variable: EMPLOYEE ENGAGEMENT

Dari tabel hasil regresi menunjukkan bahwa nilai koefisien regresi Entepreneurial Leadership terhadap Organizational Trust sebesar 0.467 dengan standar error 0.036 dan nilai signifikansi 0.000. Kemudian untuk Organizational Trust nilai koefisien regresinya sebesar 0.463 dengan standar error 0.037 dan nilai signifikansi 0.000, sehingga Entepreneurial Leadership secara signifikan berpengaruh langsung terhadap Organizational Trust, demikian pula Organizational Trust signifikan berpengaruh langsung terhadap Employee Engagement. Jika digambarkan akan terbentuk model seperti gambar di bawah.

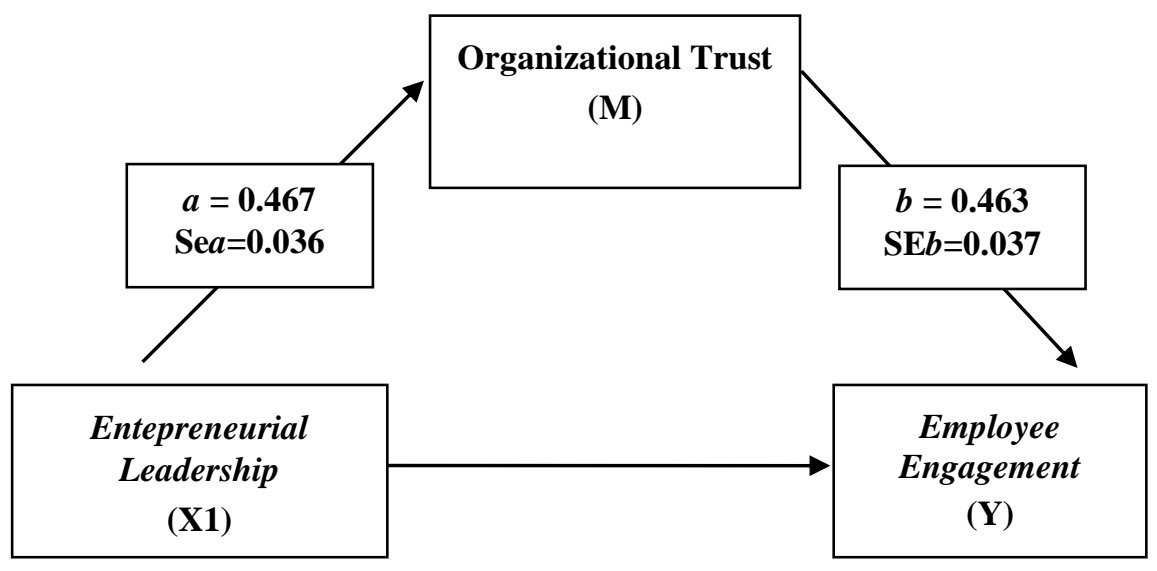

Gambar 2. Organizational Trust sebagai Mediator Entepreneurial Leadership terhadap Employee Engagement

Model di atas merupakan model yang terbentuk dari hasil regresi pertama dan kedua, sehingga membentuk model analisis jalur (path analysis) dengan variabel Organizational Trust sebagai mediatornya. Nilai z dari Sobel Test tidak dapat dihasilkan langsung dari hasil regresi, tetapi dengan perhitungan secara manual dengan rumus Sobel Test. Dari hasil perhitungan diperoleh nilai $\mathrm{Z}$ sebesar $\mathbf{9 . 0 0 6}>$ dari 1.96 .

\section{Budaya Kerja berpengaruh tidak langsung terhadap Employee Engagement melalui Organizational Trust}

Hasil uji model regresi dengan SPSS, menggunakan 3 variabel yaitu Budaya Kerja sebagai variabel dependen, Organizational Trust sebagai Mediator dan Employee Engagement sebagai variabel dependennya. Langkah regresi dilakukan sebanyak 2 kali. Regresi pertama dilakukan antara Budaya Kerja terhadap Organizational Trust dan 
Employee Engagement, dan kemudian regresi kedua antara Organizational Trust dengan Employee Engagement.

Tabel 4. Koefisien Budaya Kerja dan Organizational Trust terhadap Employee Engagement

\begin{tabular}{|c|c|c|c|c|c|c|}
\hline \multicolumn{7}{|c|}{ Coefficients $^{\mathrm{a}}$} \\
\hline \multirow{2}{*}{\multicolumn{2}{|c|}{ Model }} & \multicolumn{2}{|c|}{$\begin{array}{l}\text { Unstandardized } \\
\text { Coefficients }\end{array}$} & \multirow{3}{*}{$\begin{array}{c}\text { Standardized } \\
\text { Coefficients } \\
\text { Beta }\end{array}$} & \multirow[t]{2}{*}{$\mathrm{t}$} & \multirow[t]{2}{*}{ Sig } \\
\hline & & B & Std. Error & & & \\
\hline \multirow[t]{3}{*}{1} & (Constant) & 31.038 & 6.178 & & 5.024 & .00 \\
\hline & BUDAYA KERJA & .252 & .040 & .271 & 6.275 & .00 \\
\hline & $\begin{array}{l}\text { ORGANIZATIONAL } \\
\text { TRUST }\end{array}$ & .519 & .042 & .528 & $\begin{array}{r}12.24 \\
8\end{array}$ & $\begin{array}{r}.00 \\
0\end{array}$ \\
\hline
\end{tabular}

Dari tabel hasil regresi menunjukkan bahwa nilai koefisien regresi Budaya Kerja terhadap Organizational Trust sebesar 0.252 dengan standar error 0.040 dan nilai signifikansi 0.000 . Kemudian untuk Organizational Trust nilai koefisien regresinya sebesar 0.519 dengan standar error 0.042 dan nilai signifikansi 0.000, sehingga Budaya Kerja secara signifikan berpengaruh langsung terhadap Organizational Trust, demikian pula Organizational Trust signifikan berpengaruh langsung terhadap Employee Engagement. Jika digambarkan akan terbentuk model.

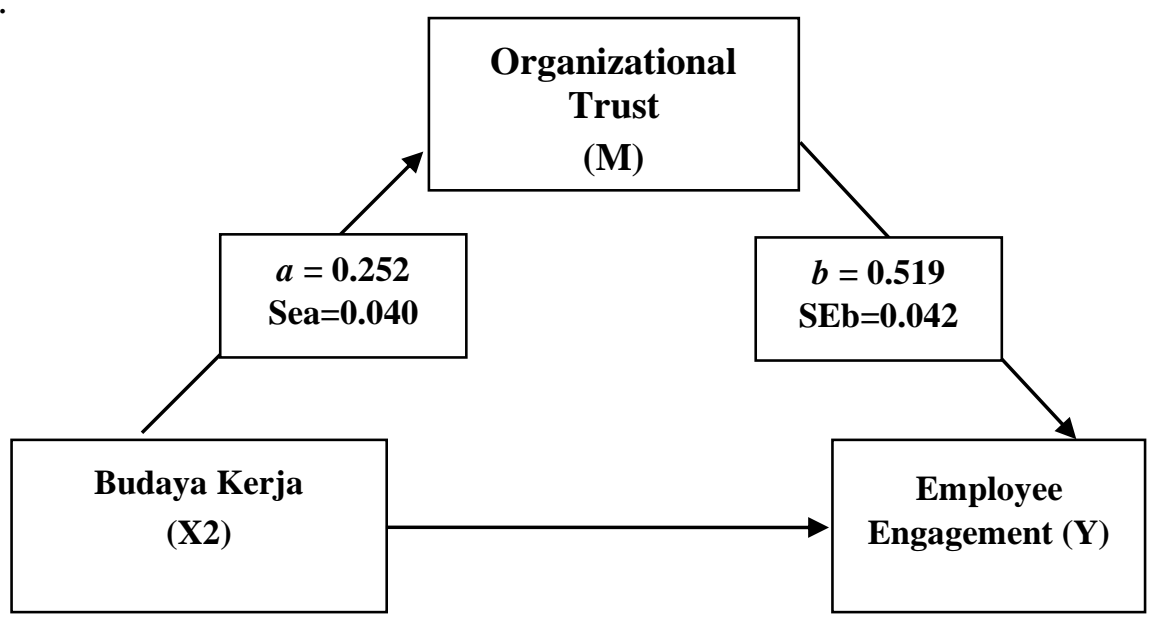

Gambar 3. Organizational Trust sebagai Mediator Budaya Kerja terhadap Employee Engagement

Model di atas merupakan model yang terbentuk dari hasil regresi pertama dan kedua, sehingga membentuk model analisis jalur (path analysis) dengan variabel Organizational Trust sebagai mediatornya. Nilai z dari Sobel Test tidak dapat dihasilkan langsung dari hasil regresi, tetapi dengan perhitungan secara manual dengan rumus Sobel Test. Dari hasil perhitungan diperoleh nilai $\mathrm{Z}$ sebesar $\mathbf{5 . 6 1 3}>$ dari 1.96 .

\section{Pengujian Hipotesis}

Menjelaskan mengenai pengujian tiga hipotesis yang diteliti. Pertama, pengujian hipotesis pengaruh langsung Entepreneurial Leadership terhadap Employee Engagement. Kedua, pengujian hipotesis pengaruh langsung Budaya Kerja terhadap Employee Engagement. Ketiga, pengujian hipotesis pengaruh langsung Organizational Trust terhadap Employee Engagement. 
Tabel 5. Rekapitulasi Pengujian Hipotesis Uji Sobel Test

\begin{tabular}{|c|c|c|c|c|c|c|c|c|}
\hline Hip & Uji Statistik & $\begin{array}{l}\text { Koefisien } \\
\text { Jalur }\end{array}$ & Koefisien & thitung & $\mathbf{t}_{\text {tabel }}$ & $\mathbf{Z}_{\text {hitung }}$ & $\begin{array}{c}\mathbf{Z}_{\text {batas }} \\
\text { nilai } \\
\text { kritis }\end{array}$ & Keputusan \\
\hline 1 & $\begin{array}{l}\mathrm{H}_{0}: \beta y 1 \leq 0 \\
\mathrm{H}_{1}: \beta y 1>0\end{array}$ & $\rho y 1=0.445$ & & 10.716 & 1.967 & & & $\mathbf{H}_{0}$ ditolak \\
\hline \multirow[t]{5}{*}{2} & \multirow{5}{*}{$\begin{array}{l}\mathrm{H}_{0}: \beta y 21=0 \\
\mathrm{H}_{1}: \beta y 21 \neq 0\end{array}$} & \multirow[t]{5}{*}{$\begin{array}{l}\rho y 1=0.531 \\
\rho y 2=0.165\end{array}$} & $a=0.520$ & & & & & Ho ditolak \\
\hline & & & $b=0.153$ & & & & & $\mathbf{H}_{0}$ ditolak \\
\hline & & & $\mathrm{SE}_{\mathrm{a}}=0.048$ & 10.787 & & & & \\
\hline & & & $S E_{b}=0.046$ & 3.345 & & & & \\
\hline & & & & & & 3.180 & 1.96 & Ho ditolak \\
\hline 3 & $\begin{array}{l}\mathrm{H}_{0}: \beta \mathrm{y} 1 \leq 0 \\
\mathrm{H}_{1}: \beta \mathrm{y} 1>0\end{array}$ & $\rho y 1=0.445$ & & 2.401 & 1.967 & & & $\mathbf{H}_{0}$ ditolak \\
\hline \multirow[t]{5}{*}{4} & \multirow{5}{*}{$\begin{array}{l}\mathrm{H}_{0}: \beta y 31=0 \\
\mathrm{H}_{1}: \beta y 31 \neq 0\end{array}$} & \multirow{5}{*}{$\begin{array}{l}\rho y 1=0.476 \\
\rho y 3=0.472\end{array}$} & $a \quad=0.467$ & & & & & $\mathbf{H}_{0}$ ditolak \\
\hline & & & $b \quad=0.463$ & & & & & Ho ditolak \\
\hline & & & $\mathrm{SE}_{\mathrm{a}}=0.036$ & 12.812 & & & & \\
\hline & & & $\mathrm{SE}_{\mathrm{b}}=0.037$ & 12.685 & & & & \\
\hline & & & & & & 9.006 & 1.96 & Ho ditolak \\
\hline 5 & $\begin{array}{l}\mathrm{H}_{0}: \beta y 2 \leq 0 \\
\mathrm{H}_{1}: \beta y 2>0\end{array}$ & ру2 $=0.069$ & & 1.651 & 1.967 & & & $\mathrm{H}_{0}$ diterima \\
\hline \multirow[t]{5}{*}{6} & \multirow[t]{5}{*}{$\begin{array}{l}\mathrm{H}_{0}: \beta y 32=0 \\
\mathrm{H}_{1}: \beta y 32 \neq 0\end{array}$} & \multirow[t]{5}{*}{$\begin{array}{l}\rho y 2=0.271 \\
\rho y 3=0.528\end{array}$} & $a=0.252$ & & & & & $\mathbf{H}_{0}$ ditolak \\
\hline & & & $b=0.519$ & & & & & Ho ditolak \\
\hline & & & $\mathrm{SE}_{\mathrm{a}}=0.040$ & 6.275 & & & & \\
\hline & & & $S E_{b}=0.042$ & 12.248 & & & & \\
\hline & & & & & & 5.613 & 1.96 & Ho ditolak \\
\hline
\end{tabular}

Sumber: data diolah, 2021

Keterangan:

Signifikansi pada $\alpha 0.05\left(Z_{\text {batas nilai kritis }}= \pm 1.96\right)$, nilai $\rho$ yang dilaporkan diambil dari distribusi normal unit dengan asumsi uji-z dua sisi dari hipotesis bahwa efek yang dimediasi sama dengan nol dalam populasi. Nilai +/- 1.96 adalah nilai kritis dari rasio uji yang berisi $95 \%$ dari pusat distribusi normal unit.

Berdasarkan hasil perhitungan statistik verifikatif dapat dibuktikan bahwa Entepreneurial Leadership berkontribusi terhadap Employee Engagement, karena dari statistik diketahui bahwa Thitung $=10.787$ (dalam koefisien jalur) dan Ttabel $=1.967$, serta Thitung $=10.716$ (dalam koefisien pengaruh langsung) dan Ttabel=1.967, sehingga Thitung $>$ Ttabel. Dengan demikian, dapat dinyatakan terdapat pengaruh langsung positif dan signifikan. Selain itu, dari hasil perhitungan statistik verifikatif dapat diketahui bahwa Entepreneurial Leadership berkontribusi terhadap Budaya Kerja, karena $\mathrm{T}$ hitung sebesar $3.345>$ ttabel 1.967 . Selanjutnya, dari hasil penelitian statistik verifikatif bahwa Entepreneurial Leadership berkontribusi terhadap Employee Engagement melalui Budaya Kerja dapat dibuktikan melalui perhitungan statistik yang memperoleh Zhitung $=3.180$ lebih besar dibandingkan dengan $\mathrm{Z}=+$ 1.96, sebagai standar nilai kritis dari rasio uji yang berisi $95 \%$ dari pusat distribusi normal. Karena Zhitung=3.180 di luar batas rasio, maka dapat dinyatakan terdapat pengaruh tidak langsung positif dan signifikan berdasarkan hasil perhitungan uji Sobel Test.

Dengan demikian dapat disimpulkan bahwa Budaya Kerja (M) dapat memediasi hubungan Entepreneurial Leadership terhadap Employee Engagement. Untuk dapat mewujudkan engagement Pegawai Kementerian Agama, maka entepreneurial leadership harus mampu menciptakan budaya kerja kondusif terlebih dahulu. Berdasarkan hasil penelitian 
statistik verifikatif dapat dibuktikan bahwa Entepreneurial Leadership berkontribusi terhadap Employee Engagement, karena dari statistik diketahui bahwa thitung=12.812 (dalam koefisien jalur) dengan Ttabel $=1.967$, serta thitung $=10.716$ (dalam koefisien hubungan langsung) dengan Ttabel $=1.967$, sehingga thitung $>$ Ttabel. Dengan demikian, dapat dinyatakan terdapat pengaruh langsung positif dan signifikan.

Selain itu, dari hasil perhitungan statistik verifikatif dapat diketahui bahwa Entepreneurial Leadership berkontribusi terhadap Organizational Trust, karena t hitung sebesar $12.685>$ Ttabel 1.967. Selanjutnya, dari hasil penelitian statistik verifikatif bahwa Entepreneurial Leadership berkontribusi terhadap Employee Engagement melalui Organizational Trust dapat dibuktikan melalui perhitungan statistik yang memperoleh Zhitung $=9.006$ dan $Z=+1.96$, dengan standar nilai kritis dari rasio uji yang berisi $95 \%$ dari pusat distribusi normal, karena Zhitung=9.006 di luar batas rasio, maka dapat dinyatakan terdapat pengaruh tidak langsung positif dan signifikan berdasarkan hasil perhitungan uji Sobel Test. Dengan demikian dapat disimpulkan bahwa Organizational Trust (M) dapat memediasi hubungan Entepreneurial Leadership terhadap Employee Engagement. Untuk dapat mewujudkan engagement pegawai Kementerian Agama, maka Pimpinan Kementerian Agama yang menerapkan entepreneurial leadership harus mampu menciptakan organizational trust terlebih dahulu. Berdasarkan hasil perhitungan statistik verifikatif, kontribusi Budaya Kerja terhadap Employee Engagement tidak signifikan, karena dari statistik diketahui bahwa thitung= 1.651 (dalam koefisien hubungan langsung) lebih kecil dari Ttabel= 1.967 dengan signifikansi $0.100>0.05$. Namun demikian, hubungan tersebut menjadi signifikan dalam koefisien jalur dengan dimediasi oleh Organizational Trust, karena nilai thitung berubah menjadi 6.275 lebih besar dari Ttabel= 1.967. Dengan demikian, dapat dinyatakan terhadap pengaruh langsung positif antara Budaya Kerja terhadap Employee Engagement dengan dimediasi oleh Organizational Trust.

Hal ini kemudian diperkuat dengan perhitungan statistik verifikatif yang menunjukkan bahwa Budaya Kerja berkontribusi terhadap Organizational Trust, karena t hitung sebesar $12.248>$ ttabel 1.967. Selanjutnya, dari hasil penelitian statistik verifikatif bahwa Budaya Kerja berkontribusi terhadap Employee Engagement melalui Organizational Trust dapat dibuktikan melalui perhitungan statistik yang memperoleh Zhitung $=5.613$ dengan standar $\mathrm{Z}=+1.96$, adalah nilai kritis dari rasio uji yang berisi $95 \%$ dari pusat distribusi normal, karena Zhitung=5.613 di luar batas rasio, maka dapat dinyatakan terdapat pengaruh tidak langsung positif dan signifikan berdasarkan hasil perhitungan Sobel Test.

Dengan demikian dapat disimpulkan bahwa Organizational Trust (M) dapat memediasi hubungan Budaya Kerja terhadap Employee Engagement. Untuk dapat mewujudkan engagement Pegawai Kementerian Agama, maka Budaya Kerja harus mampu menciptakan Organizational Trust terlebih dahulu.

\section{KESIMPULAN}

Disimpulkan bahwa Organizational Trust dapat memediasi hubungan Budaya Kerja terhadap Employee Engagement. Hal ini menunjukkan bahwa untuk meningkatkan Employee Engagement Pegawai di Kementerian Agama, maka terlebih dahulu Budaya Kerja harus mampu meningkatkan terlebih dahulu trust Pegawai Kementerian Agama terhadap organisasi Kementerian Agama. Berdasarkan kesimpulan tersebut, dapat direkomendasikan agar para pimpinan di Kementerian Agama disarankan menerapkan model kepemimpinan entepreneurial yang mampu menumbuhkan budaya kerja positif dan peningkatan kepercayaan pegawai terhadap organisasi (organizational trust) dan mengimplementasikannya di berbagai level jabatan pimpinan di lingkungan Kementerian Agama sehingga employee engagement dapat tumbuh di seluruh unit dan level organisasi Kementerian Agama.. 


\section{DAFTAR PUSTAKA}

Akbar, A. (2020). Assessing recycling potential of carbon fiber reinforced plastic waste in production of eco-efficient cement-based materials. Journal of Cleaner Production, $274,123001$.

Anitha, J. (2014). Determinants of employee engagement and their impact on employee performance. . International journal of productivity and performance management.

Babu, K. S. (2020). Non-standard interactions in radiative neutrino mass models. Journal of High Energy Physics, 2020(3. 1-120.

Bija, A. P. (2020). Influence of Leadership Style, Work Culture, and Job Satisfaction on Employee Engagement. KnE Social Sciences, 376-388.

Candrasari, D. S. (2020). Medicinal effect, in silico bioactivity prediction, and pharmaceutical formulation of Ageratum conyzoides L.: . A review. Scientifica.

Christian, M. S. (2011). Work engagement: A quantitative review and test of its relations with task and contextual performance. . Personnel psychology, 64(1), 89-136.

Chughtai, A. A. (2013). Exploring the impact of trust on research scientists' work engagement: Evidence from Irish science research centres. . Personnel Review.

Chughtai, A. B. (2015). Linking ethical leadership to employee well-being: The role of trust in supervisor. Journal of Business Ethics, 128(3), 653-663.

Colquitt, J. A. (2009). Organization Behavior: Improving Performance and Commitment in the Workpalce. New York: McGraw-Hill Education.

Dabić, M., Stojčić, N., Simić, M., Potocan, V., Slavković, M., \& Nedelko, Z. (2020). Intellectual agility and innovation in micro and small businesses: The mediating role of entrepreneurial leadership. Journal of Business Research, 123, 683-695. https://doi.org/10.1016/j.jbusres.2020.10.013

Fernald, L. W. (2005). A new paradigm: Entrepreneurial leadership. Southern business review, $30(2), 1-10$.

Galanaki, E. (2009). Leadership's impact on employee engagement: Differences among entrepreneurs and professional CEOs. Leadership \& Organization Development Journal.

Gallup Jr, G. G. (2004). Where am I? The neurological correlates of self and other. . Cognitive brain research, 19(2), 114-122.

Hartini, S. (2018). The development of physics teaching materials based on local wisdom to train saraba kawa character. Jurnal Pendidikan IPA Indonesia, 7(2), 130-137.

Koyuncu, M. (2006). Work engagement among women managers and professionals in a Turkish bank: Potential antecedents and consequences. Equal Opportunities International.

Lee, D. Y. (2001). The effects of entrepreneurial personality, background and network activities on venture growth. Journal of management studies, 583-602.

Renko, M., El Tarabishy, A., Carsrud, A. L., \& Brännback, M. (2013). Understanding and measuring entrepreneurial leadership style. Journal of Small Business Management, 53(1), 54-74. https://doi.org/10.1111/jsbm.12086

Rich, B. L. (2010). Job engagement: Antecedents and effects on job performance. Academy of management journal, 53(3), 617-635.

Saks, A. M. (2011). Getting newcomers engaged: The role of socialization tactics. Journal of managerial psychology.

Saragih, J. (2020). Pifuhd: Multi-level pixel-aligned implicit function for high-resolution 3d human digitization. In Proceedings of the IEEE/CVF Conference on Computer Vision and Pattern Recognition, 84-93. 
Schaufeli, W. B. (2007). Efficacy or inefficacy, that's the question: Burnout and work engagement, and their relationships with efficacy beliefs. Anxiety, stress, and coping, 20(2), 177-196 .

Ugwu, E. O. (2013). Acceptability of human papilloma virus vaccine and cervical cancer screening among female health-care workers in Enugu, Southeast Nigeria. . Nigerian journal of clinical practic.

Yildiz, R. Ö. (2017). The Effect Of Organizational Trust On Work Engagement: An Application On Logistics Personnel. The International New Issues in Social Sciences, 5(5), 139-158.

Yulianti, N. (2016). Pengaruh model inkuiri terbimbing berbasis lingkungan terhadap kemampuan pemahaman konsep dan karakter. Jurnal Cakrawala Pendas, 2(2), 266437. 